\title{
IMPLEMENTASI PENDIDIKAN KARAKTER DALAM MEMBENTUK TINGKAH LAKU SANTRI DI PONDOK PESANTREN RIYADLUL HUDA KUNINGAN
}

\author{
Tuti Tursilah \\ Tutitursilah72@gmail.com \\ Universitas Islam Al-Ihya Kuningan
}

\begin{abstract}
ABSTRAK
Konteks dari penelitian ini adalah adanya degradasi jati diri, krisis karakter, menurunnya martabat bangsa, dan dekadensi moral yang sedang melanda bangsa Indonesia. Hal ini merupakan akibat dari gagalnya pendidikan yang diterapkan. Pesantren merupakan lembaga keagamaan yang tepat untuk menyelamatkan generasi muda dari dekadensi moral tersebut. Karena pesantren memiliki karakteristik yang khas yaitu sarat nilai dan tradisi yang luhur untuk menyikapi globalisasi secara kritis dan bijak. Sehingga melalui pendidikan karakter di pesantren aspek afektif dan psikomotorik dapat terwujud.
\end{abstract}

Kata kunci : Pendidikan Karakter, Tingkah Laku

\begin{abstract}
The context of this research is the degradation of identity, a crisis of character, the erosion of the dignity of the nation, and the moral decadence that is currently afflicting the nation of Indonesia. This is a result of the failure of education that is applied. Boarding school is religious institutions the right to save the young generation from the moral decadence. Because it has characteristics of a typical boarding school that is full of noble values and traditions for addressing globalization critically and wisely. So through character education at boarding school affective and psychomotor aspects can be realized.
\end{abstract}

Keywords: Character education, Behavior 


\section{PENDAHULUAN}

Pendidikan adalah proses internalisai budaya kedalam diri seseorang dan masyarakat sehingga membuat orang dan masyarakat jadi beradab Telah diketahui bahwa sampai kapanpun pendidikan masih menjadi sarana efektif untuk mencerdaskan kehidupan bangsa. Maju tidaknya suatu bangsa bisa dilihat dari perkembangan pendidikan yang sudah berjalan mewarnai lebih dari setengah abad kemerdekaan Indonesia. Namun, persoalan bangsa ini terlalu kompleks untuk mengatakan bahwa pendidikan Indonesia sudah mencapai titik kemajuan yang signifikan. Bahkan bisa dikatakan, pendidikan Indonesia masih belum beranjak dari tidur panjangnya untuk membangun masa depan yang penuh dengan prestasi membanggakan.

Bangsa kita saat ini tengah menghadapi krisis karakter atau jati diri yang menjadi landasan fundamental bagi karakter bangsa. Berbagai kejadian atau peristiwa yang sering berlangsung dalam kehidupan sehari-hari yang bisa disaksikan melalui televisi maupun media cetak, menunjukkan betapa masyarakat kita tengah mengalami degradasi jati diri dan menurunnya martabat bangsa yang berkeadaban. Seiring perjalanan waktu, moral bangsa terasa semakin amburadul,huru-hara, kesewenangan, ketimpangan, dan pergaulan bebas dikalangan remaja terjadi dimana-mana, tata krama pun hilang, nyawa seperti tak ada harganya, korupsi menjadi-jadi bahkan telah dilakukan terang-terangan dan berjamah.

Oleh karena itu, dengan adanya pendidikan karakter diharapkan akan mampu menjadikan bangsa ini lebih baik lagi. Karena secara tidak langsung pendidikan adalah sarana strategis dalam pembentukan karakter. Maka sebagai langkah awal pendidikan karakter dapat diterapkan di institusi pendidikan formal maupun nonformal, disamping di lingkungan keluarga. 


\section{PEMBAHASAN}

Pendidikan karakter adalah upaya yang terencana untuk menjadikan peserta didik mengenal, peduli, dan menginternalisasi nilai-nilai sehingga peserta didik berperilaku sebagai insan kamil. Thomas Lickona mendefinisikan orang yang berkarakter sebagai sifat alami seseorang dalam merespon situasi secara bermoral, yang dimanifestasikan dalam tindakan nyata melalui tingkah laku yang baik, jujur, bertanggung jawab, menghormati orang lain dan karakter mulia lainnya. Pengertian ini mirip dengan apa yang diungkapkan Aristoteles bahwa karakter itu erat kaitannya dengan habit atau kebiasaan yang terus-menerus dilakukan.

Menurut tokoh muslim, Imam Al-Ghazali berpendapat bahwa karakter lebih dekat dengan akhlak, yaitu spontanitas manusia dalam bersikap, atau melakukan perbuatan yang telah menyatu dalam diri manusia sehingga ketika muncul tidak perlu dipikirkan lagi. Akhlak merupakan fondasi dasar sebuah karakter diri. Sehingga pribadi yang berakhlak baik nantinya akan menjadi bagian dari masyarakat yang baik pula. Akhlak dalam Islam juga memiliki nilai yang mutlak karena persepsi antara akhlak baik dan buruk memiliki nilai yang dapat diterapkan pada kondisi apapun. Tentu saja, hal ini sesuai dengan fitrah manusia yang menempatkan akhlak sebagai pemelihara eksistensi manusia sebagai makhluk yang paling mulia. Akhlaklah yang membedakan karakter manusia dengan makhluk yang lainnya. Tanpa akhlak manusia akan kehilangan derajat sebagai hamba Allah yang terhormat. Pembinaan akhlak merupakan bagian integral dan tak terpisahkan dalam dunia pendidikan. Karena tujuan pendidikan dalam Islam adalah menciptakan manusia yang beriman dan bertakwa melalui ilmu pengetahuan, keterampilan, dan berperilaku sesuai nilai-nilai Islam.

Akhlak merupakan tingkah laku tanpa disadari, karena telah menyatu dalam diri seseorang. Tingkah laku adalah semua tindakan manusia yang bisa diamati, diukur, dan dinilai. Namun, di era modern ini tingkah laku manusia sudah sangat memprihatinkan. Diakui dan disadari atau tidak, perilaku masyarakat kita terutama remaja dan anak-anak menjadi 
sangat mengkhawatirkan karena banyaknya hal-hal negatif. Alasan kemerosotan moral, dekadensi kemanusiaan yang sesungguhnya terjadi tidak hanya dalam generasi muda, tetapi telah menjadi ciri khas abad ini. Kehidupan manusia pada masa kini diwarnai dengan kemajuan dalam berbagai bidang. Perkembangan ilmu pengetahuan dan teknologi telah membawa manusia kepada taraf kehidupan yang relatif lebih maju. Hal ini merupakan keberhasilan manusia dalam rangka mengembangkan dirinya. Sebagai sebuah agama, Islam berkembang melalui dua macam struktur, yaitu struktur keyakinan dan struktur peribadatan. Saat ini kita tengah berada dipusaran hegemoni media, revolusi ilmu pengetahuan (iptek), yang tidak hanya mampu menghadirkan sejumlah kemudahan dan kenyamanan hidup bagi manusia modern, tetapi juga mengundang serentetan persoalan dan kekhawatiran. Kemajuan ilmu pengetahuan dan teknologi dapat mengurangi atau bahkan menihilkan kemanusiaan atau yang disebut dehumanisasi.

Menurut Nurcholis Madjid kegagalan pendidikan agama disebabkan pembelajaran Pendidikan Agama Islam lebih menitikberatkan pada hal-hal yang bersifat formal dan hafalan, bukan pada pemaknaannya. Proses pembelajarannya selama ini cenderung lebih diarahkan pada pencapaian target kurikulum dan bukan diarahkan pada pencapaian dan penguasaan kompetensi, akan tetapi terfokus pada aspek kognitif sehingga pembelajaran identik dengan hafalan dan ceramah. Karena jika pembelajaran hanya difokuskan pada aspek kognitif saja, maka tujuan dari pendidikan tidak akan terwujud. Dan hanya akan terlahir generasi bangsa yang unggul dalam bidang pengetahuan namun tidak memiliki tingkah laku yang terpuji.

Keadaan ini seharusnya membuat kita perlu mempertimbangkan kembali bagaimana lingkungan keluarga, sekolah, dan masyarakat sehingga mampu menyumbangkan perannya bagi perbaikan karakter. Sebenarnya, persoalan karakter tidak sepenuhnya terabaikan. Akan tetapi dengan fakta seputar kemerosotan karakter saat ini, seperti yang telah disebutkan di 
atasbahwa ada kegagalan pada pendidikan yang telah diterapkan dalam hal menumbuhkan remaja dan anak-anak yang berkarakter dan berakhlak mulia. Padahal karakter yang positif atau mulia yang dimiliki remaja dan anak-anak kelak akan mengangkat status derajatnya.

Penanaman pendidikan karakter yang lebih ditekankan ini, persoalan yang demikian dapat dikurangi. Pesantren dikenal sebagai institusi pendidikan Islam sebagai pusat ilmu keagamaan. Pesantren adalah lembaga yang sarat nilai dan tradisi luhur yang telah menjadi karakteristiknya. Pesantren dengan teologi yang dianutnya hingga kini, ditantang untuk menyikapi globalisasi secara kritis dan bijak. Pesantren harus mampu mencari solusi yang benar-benar mencerahkan sehingga, pada satu sisi dapat menumbuh kembangkan kaum yang tidak hanya religius tetapi berintelektualitas yang memiliki wawasan luas yang tidak gamang menghadapi modernitas dan sekaligus tidak kehilangan identitas dan jati dirinya. Dalam menghadapi globalisasi tersebut, bagaimana pesantren mengembangkan dan melabuhkan nilai-nilainya dalam hidup keseharian santri, serta merumus ulang nilai-nilai tersebut dalam konteks kekinian. Sebab tanpa adanya upaya ini, nilai-nilai tersebut akan menjadi simbolsimbol formalistik yang tidak menjadi sumber rujukan dalam sikap dan perilaku santri. Strategi dasar yang perlu dilakukan untuk mencapai ke arah itu adalah pengembalian pendidikan karakter pada makna hakiki. Dewasa ini pendidikan telah mengalami pembiasan arti dengan melihatnya sekedar sebagai wacana pengajaran yang lebih menitikberatkan kepada transfer pengetahuan semata. Pendidikan perlu diarahkan sebagai proses penanaman nilai-nilai dan perluasan wawasan serta kemampuan manusia sehingga mereka benar-benar tercerahkan.

Makna yang terkandung dalam pendidikan karakter adalah untuk membentuk kepribadian manusia. Keberhasilan pendidikan pada masa kanak- kanak pada akhirnya dimunculkan pada perbuatan dan perilaku. Islam datang untuk mengantarkan manusia kejenjang kehidupan yang gemilang dan bahagia sejahtera melalui berbagai segi. Dalam 
kemajuan ilmu pengetahuan dan teknologi yang dialami sekarang ini tidak sedikit dampak negatifnya terhadap kehidupan atas kemajuan yang dialaminya, sehingga pada saat ini manusia terlampau mengejar materi, tanpa menghiraukan nilai-nilai spiritual yang sebenarnya berfungsi untuk memelihara dan mengendalikan akhlak. Karena tradisi yang dimiliki pesantren, telah memberikan banyak peluang untuk menyelesaikan beragam persoalan kemanusiaan. Tradisi pesantren, seperti keikhalasan, kesederhanaan, keteladanan, dan kemandirian adalah aset (kekayaan) moral yang dapat dijadikan dasar dalam pendidikan untuk menghentikan proses penghancuran manusia yang pada intinya berawal dari kemandulan pendidikan dewasa ini. Tradisi tersebut perlu dirumuskan dalam suatu pola pendidikan sistematis yang dapat dikontekstualisasikan dengan hidup kekinian. 


\section{KESIMPULAN}

Pesantren didefinisikan sebagai suatu tempat pendidikan dan pengajaran yang menekankan pelajaran agama Islam dan didukung asrama sebagai tempat tinggal santri yang bersifat permanen. Pesantren adalah sebuah kawasan yang khas yang ciri-cirinya tidak dimiliki oleh kawasan yang lain. Secara garis besar, tipologi pesantren bisa dibedakan paling tidak menjadi tiga jenis, walaupun agak sulit untuk membedakan secara ekstrim diantara tipetipe tersebut yaitu salafiyah (tradisional), khalafiyah (modern), dan terpadu.

Institusi Pendidikan Islam berupa pesantren dan madrasah diyakini memiliki peranan strategis dalam merespon dampak globalisasi, dalam menciptakan anak didik atau generasi muda berkarakter yang dapat bertindak sebagai 'pemain'. Sama halnya dengan pesantren, sejak lama memiliki peran strategis pula dalam menciptakan perubahan sosial, termasuk peran para elit pesantren dalam kiprah dalam perjuangan kemerdekaan Republik Indonesia

Pendidikan karakter dalam membentuk tingkah laku santri tercermin dalam aktivitas keseharian seperti keikhlasan, kesederhanaan, kemandirian, ukhuwah islamiyah, dan kejujuran. Mereka ikhlas melaksanakan tugas dan kewajibannya, sudah bisa menerima apa adanya, mandiri dalam melakukan segala sesuatu, tidak membeda-bedakan dalam berteman, dan jujur dalam perkataan atau perbuatan. Santri juga telah mempraktikkan dalam kehidupan sehari-hari nilai-nilai yang di dapat dalam pembelajaran di madrasah diniyah. Diantaranya fiqih yang berkaitan dengan ibadah dan akhlak yang berkaitan dengan tingkah laku. 


\section{DAFTAR RUJUKAN}

A'la, Abd. 2006. Pembaharuan Pesantren. Yogyakarta: Pustaka Pesantren.

Arifin, Zainal. 2016. Evaluasi Pembelajaran. Bandung: Remaja Rosdakarya. Arikunto,

Suharsimi. 2013. Prosedur Penelitian Suatu Pendekatan Praktik.

Jakarta: Rineka Cipta.

Aunillah, Nur Isna. 2011. Panduan Menerapkan Pendidikan Karakter Di Sekolah. Yogyakarta: Laksana.

Bruinessen, Martin van. 1999. Kitab Kuning, Pesantren, dan Tarekat: Tradisi-tradisi Islam di Indonesia. Bandung: Mizan

Darmawan, Deni. 2014. Metode Penelitian Kuantitatif. Bandung: Remaja Rosdakarya.

Daryanto dan Dwicahyono, Aris. 2014. Pengembangan Perangkat Pembelajaran. Yogyakarta: Gava Media.

Departemen Agama RI. 2010. Al-Hidayah Al-Qur'an Tafsir Per Kata Tajwid Kode Angka. Tangerang: Kalim.

Departemen Pendidikan Nasional. 2011. Kamus Besar Bahasa Indonesia. Jakarta: Gramedia Pustaka Utama.

Desmita. 2012. Psikologi Perkembangan Peserta Didik. Bandung: Remaja Rosdakarya.

Fitri, Agus Zaenul. 2012. Pendidikan Karakter Berbasis Nilai dan Etika di Sekolah. Yogyakarta: Ar-Ruzz Media.

Hamid, Hamdani dan Saebani, Beni Ahmad. 2013. Pendidikan Karakter Perspektif Islam. Bandung: CV. Pustaka Setia.

Idi, Abdullah dan Hd, Safarina. 2016. Etika Pendidikan: Keluarga, Sekolah, dan Masyarakat. Jakarta: Rajawali Pers.

Ilahi, Mohammad Takdir. 2014. Gagalnya Pendidikan Karakter: Analisis \& Solusi Pengendalian Karakter Emas Anak Didik. Yogyakarta: Ar-Ruzz Media.

Kartono, Kartini. 1996. Psikologi Umum. Bandung: Mandar Maju.

Koesoema A, Doni. 2007. Pendidikan Karakter: Strategi Mendidik Anak di Zaman Global. Jakarta: PT Grasindo.

Kuniawan, Asep. Pendidikan Karakter di Pondok Pesantren dalam Menjawab Krisis Sosial. IAIN Syekh Nurjati Cirebon 